\title{
Focus on psychiatry in New Zealand
}

\author{
PETER R. JOYCE
}

New Zealand has been inhabited by the indigenous Maori people for more than 1000 years. The first European (Pakeha) to see the country, in 1642 , was the Dutch explorer Abel Tasman. But the English explorer James Cook, who landed there in 1769, was responsible for New Zealand becoming part of the British Empire and, later, the British Commonwealth. In 1840 the Treaty of Waitangi was signed between Maori leaders and LieutenantGovernor Hobson on behalf of the British Government. The three articles of the Treaty gave powers of Sovereignty to the Queen of England; guaranteed to the Maori Chiefs and tribes full, exclusive and undisturbed possession of their lands, estates, forests and fisheries; and extended to the Maori people Royal protection and all the rights and privileges of British subjects.

The population of New Zealand is now approaching 4 million people. Most are of European descent, but about $15 \%$ identify themselves as Maori. Pacific Islanders constitute another important group, and immigrants from Asia are increasing in number. About half of the population lives in the top part of the North Island, where Auckland is the only New Zealand city with a population above 1 million. Auckland, the 'city of sails', is located on two harbours and is the home of the America's Cup for yachting. It is the most cosmopolitan of New Zealand's cities and is the world's largest Polynesian city. Wellington, located at the bottom of the North Island, has a population of over 300000 and is the capital city and seat of government. Christchurch, on the east coast half-way down the South Island, also has a population of over 300000 . Christchurch has been called the garden city, the most English of cities outside of England. It is the stepping-stone to the Antarctic and is New Zealand's closest approximation to America's Silicon Valley. Dunedin, the 'Edinburgh' of the South Island and the only true university city was, 100 years ago, the most prosperous of the country's cities. It has a population of about 100 000 , which, unlike the populations of the other major cities, has not increased during the past 40 years.

\section{HEALTH SERVICES}

For much of its history, New Zealand had a predominantly public health system. The public general hospitals provided free medical care but primary care (genera practice) has been based on an individual practitioner model, with patients paying fees subject to varying government rebates. Certain groups, such as children, had higher rebates and thus paid lower fees. However, during the 1990s the health system underwent radical reform and restructuring. Without either health sector consultation or public mandate, a marketdriven and competitive health system was introduced. The reforms have largely failed to produce the benefits anticipated, and the new Labour Government elected in 1999 has begun to reverse most of its elements (Hornblow, 1997; Hornblow \& Barnett, 2000). Cooperation is to replace competition and there will be a return to District Health Boards. However, it is too early to see the effects of these latest changes. One major concern is that the Ministry of Health will have an expanded role, despite its history of providing poor leadership.

\section{MENTAL HEALTH SERVICES}

Mental health services have traditionally been the Cinderella of the health services, subject to many inquiries over the years. However, a National Mental Health Strategy was introduced in the early 1990s, all the major political parties agreeing that mental health had been underfunded. Increased funding over the past 7 or 8 years has led to some real improvements in services. But developments have been patchy and the biggest issue is the lack of an adequately trained workforce. However, there are many opportunities for psychiatrists to have a real impact on the development of expanding services.

Although there are now about 130 psychiatric registrars in New Zealand, over two-thirds of whom are in Auckland and Christchurch, historical shortages mean that there remain many vacancies for psychiatrists. Before the 1970s, New Zealand trained few psychiatrists and even then part or most of the training took place in Australia, the UK or North America. The establishment of the Royal Australian and New Zealand College of Psychiatrists in 1978 resulted in an increase in the number of local psychiatric training posts that is still continuing. We are probably now training sufficient numbers to sustain an adequate workforce in the future, but for the next 5 years at least there will continue to be many vacant posts. This is why most New Zealand mental health services are constantly advertising posts in the UK and North America.

Before the founding of the College and the development of training posts, New Zealand doctors interested in psychiatry often never returned to practise in the country after their training overseas.

For most of the 20th century, in-patient psychiatric units in New Zealand were housed in large mental hospitals, often modelled on the asylums of the UK. However, the past two decades have seen the slow development of psychiatric in-patient units in general hospitals and the integration of mental health services into mainstream general health care. This period has also seen the gradual growth of community psychiatry and community mental health teams (CMHTs).

Child and adolescent psychiatry, substance misuse services, forensic psychiatry and psychogeriatric services have also been developing. For all these sub-specialities recruitment of trained psychiatrists has been an issue. There are particular shortages in child and adolescent psychiatry, and only in Christchurch are numbers of child and adolescent psychiatrists approaching sufficiency. Substance misuse services vary considerably around the country: in some centres they are integrated with mental health services, but in others they are completely separate (both physically and philosophically). 


\section{POLITICAL INFLUENCES ON MENTAL HEALTH}

Over the past decade two new political movements have had an important impact on mental health. First, as government has moved to address issues related to the Treaty of Waitangi, New Zealand's people and its health professionals have started to address the health inequities between the country's Europeans and its indigenous Maori. The current Government has a 'Closing the gaps' strategy, but this is just a step in the process of acknowledging, addressing and healing the mistreatment of the Maori tribes by the early British settlers.

Another major factor affecting mental health has been the growth of consumerism. Self-help and support groups have grown in number, strength and political importance. The availability of atypical antipsychotic drugs in New Zealand came about more because of the influence of the Schizophrenia Fellowship and related consumer groups than because of any influence of health professions or drug companies. Increasingly, psychiatrists and groups that represent both consumers and their families are working together to improve the plight of those with mental illness in New Zealand.

\section{PRIVATE PSYCHIATRY}

As New Zealand has had a predominantly public health system and a shortage of psychiatrists, private psychiatry has never been especially strong in the country. Apart from one hospital in Dunedin, there are no private psychiatric in-patient facilities, but out-patient (office-based) private psychiatry is available in all major cities. Private psychiatry in New Zealand is not especially financially lucrative. Only $40 \%$ of New Zealanders have private health insurance, and even when psychiatric care is covered by an insurance policy, the cover is not generous.

Perhaps because of our history of a public mental health service, provided from large mental hospitals, and the poor financial rewards of private psychiatry, psychodynamic psychotherapy has never been strong in New Zealand. Perhaps, too, the New Zealand psyche tends to be one of pragmatism and scepticism, and so the claims of psychoanalytical theory were never widely accepted by psychiatrists or the public. However, counselling services of all types have flourished. Sometimes the training of counsellors has been excellent, but at other times quite inadequate. The fact that the Accident Compensation Corporation (ACC) still funds counselling for the consequences of abuse led to some dubious practices and beliefs regarding the aetiological significance of childhood sexual abuse. Sometimes psychiatrists, however, were denied the right to claim for sexual abuse counselling, because it was deemed by the ACC that their medical training was insufficiently politically correct to undertake such sensitive therapy. Conversely, some counsellors with dubious training but acceptable political correctness were funded.

\section{OTHER MENTAL HEALTH PROFESSIONALS}

In addition to the shortage of psychiatrists, there are also shortages of other welltrained mental health professionals. There is a growing lack of mental health nurses and it is doubtful that we are training sufficient for the future. However, in the past 5 years academic positions in mental health nursing have been established in Auckland, Wellington and Christchurch, postgraduate courses have been set up and research in mental health nursing is beginning.

There are adequate training programmes for clinical psychology around the country, but for some areas, such as clinical child psychology, very few training opportunities exist. There are no specific psychiatric social work training programmes, and most social workers who work in mental health learn on the job.

\section{PSYCHOPHARMACOLOGY}

During the health reforms of the 1990s, the Government established Pharmac, which was briefed to contain the costs of drugs for the country's health services. Pharmac's emphasis on parsimony in drug expenditure is unpopular with most doctors and all drug companies. Already, the range of psychotropic drugs publicly available is restricted. Psychiatrists have access to the old tricyclic antidepressants and monoamine oxidase inhibitors, but only three selective serotonin reuptake inhibitors are funded (fluoxetine, paroxetine and citalopram). Among other antidepressants, we do not have venlafaxine, reboxitine, mirtazapine or buproprion.
Only after a long fight have olanzapine, risperidone and clozapine been made available. Of the anticonvulsant mood stabilisers, only carbamazepine and sodium valproate are available. Naltrexone is not available for alcohol dependence.

Many psychiatrists believe that Pharmac is especially discriminatory against mental health consumers and that the organisation has no understanding that, for some patients, drugs of the same class are not interchangeable. Pharmac focuses on the cost of the drugs, not on the total health economics, of such illnesses as schizophrenia, bipolar disorder, major depression and obsessivecompulsive disorder.

The problem is getting worse and New Zealand's psychiatry will fall increasingly behind the rest of the developed world in psychopharmacology options and expertise. Lack of a suitable modern pharmacopoeia is already affecting the decisions of individual psychiatrists' regarding whether to work in New Zealand or not. Similarly, many of the major pharmaceutical companies have cut back or closed their New Zealand branches and have stopped using the country as a site for clinical trials, despite its good record for being able to run drug trials in all areas of health. A concomitant of this is that there is less money from pharmaceutical companies to support continuing medical education, research and conferences.

\section{ACADEMIC PSYCHIATRY AND PSYCHIATRIC RESEARCH}

New Zealand has four academic departments of psychiatry or psychological medicine, in Auckland, Wellington, Christchurch and Dunedin. The first was in the Dunedin School of Medicine in the 1970s but only when Paul Mullen (of London's Maudsley Hospital) took the chair in 1982 did it become an active research department. Mullen stimulated research in epidemiological (Mullen et al, 1993) and forensic psychiatry. When he moved to the chair of forensic psychiatry in Melbourne he was succeeded by Sarah Romans, who continued epidemiological studies and stimulated research on women's mental health (Romans et al, 1995) and bipolar disorder.

During the 1970s, '80s and early '90s, New Zealand's leading psychiatric researcher was John Werry, who was the foundation professor of psychiatry at the Auckland Medical School. Werry was a leading figure in child psychopharmacology and 
undertook important research on childhood psychiatric syndromes, including childhoodonset psychotic and bipolar disorders (Werry et al, 1991). During Rob Kydd's tenure as head of department, research was developing and included work by Mark OakleyBrowne, who was involved with the Cochrane Collaboration for Depression and Anxiety and is leading a major national mental health epidemiological study.

During the 1980s and into the '90s, Christchurch emerged as the strongest research department in the country. Initial research on affective disorders focused on their neuroendocrinology, in the Christchurch School of Medicine's internationally renowned endocrinology department. In the mid-1980s a major epidemiological study was completed based on the methodology of the American National Institute of Mental Health Epidemiological Catchment Area Studies (Weissman et al, 1996). In the 1990s, clinical trials on depression, bulimia nervosa and anorexia nervosa were undertaken. These studied both psychopharmacological and psychotherapeutic treatments. The first psychotherapy trial was of cognitive-behavioural therapy (CBT) in bulimia nervosa (Bulik et al, 1998), but subsequent studies in depression and anorexia nervosa have included both CBT and interpersonal psychotherapy (McIntosh et al, 2000). Across these clinical studies there have also been major interests in personality (Mulder et al, 1999) and, increasingly, in molecular genetics (Sullivan et al, 1998).

In 1996 the Alcohol Liquor Advisory Council, after a tendering process, funded in the Christchurch endocrinology department a National Centre for Treatment Development in Alcohol, Drugs and Addiction, under the directorship of Doug Sellman. This unit has completed a first treatment trial on motivational enhancement therapy for alcohol dependence. The Centre is also actively involved with a number of studies looking at alcohol problems in Maori people (Sellman et al, 2001).

In Wellington, under the leadership of Pete Ellis and John Bushnell, major studies are underway on the interface between mental health services and primary care. Auckland has plans for a chair in child and adolescent psychiatry, and Christchurch has already advertised such a post. Hopefully, these initiatives will lead to research in this important sub-speciality.

Phil Brinded (Christchurch) is the most senior academic forensic psychiatrist in the country, and in conjunction with colleagues from Auckland he has completed a major psychiatric epidemiological study of New Zealand's prisons (Brinded et al, 1999).

Two major longitudinal child development studies have been undertaken independently of the country's four academic departments. Phil Silva led the Dunedin Multidisciplinary Health and Development Study for many years and David Fergusson has directed the Christchurch Health and Development Study since its beginning. Both studies are following birth cohorts of over 1000 children, who are now adults in their 20s. These studies are internationally renowned and although they have addressed a wide range of health issues, both have made particular contributions to child and adolescent mental health (McGee et al, 1992; Fergusson et al, 1993).

Given that drug company money is no longer easily available in New Zealand and that health research funding on a population basis is lower in New Zealand than in Australia, Canada, the UK or the USA, it is not an easy environment in which psychiatric research can develop and grow. However, despite these difficulties research has grown much stronger over the past 10 years. But there is considerable scope for further development and improvement.

\section{CONCLUSIONS}

Despite marked shortages of psychiatrists and other well-trained mental health professionals, during the past decade New Zealand has made major advances in delivering better mental health care. All political parties accept the need for ongoing increases in funding of mental health services, to make up for the inadequate investment of the past. Many improvements have already resulted from greater injections of funds, but developments have been inconsistent and there remain many opportunities for better services and for psychiatrists willing to take on leadership roles in developing them.

During the coming decade I hope that we will see a gradual correction of workforce deficiencies and a more consistent delivery of better mental health care. Concurrently, psychiatric research should continue to develop. I also hope that Pharmac will be more generous in the funding of new psychotropic drugs, so that people with mental illness can receive the best treatments, delivered by competent mental health professionals in all parts of the country.

\section{DECLARATION OF INTEREST}

P.R.J.'s research is funded primarily by the Health Research Council of New Zealand, the University of Otago and the Mental Health Division of Canterbury Health.

\section{REFERENCES}

Brinded, P. M. J., Fairley, N., Malcolm, F., et al (1999)

The Christchurch Prisons Psychiatric Epidemiology Study: methodology and prevalence rates for psychiatric disorders. Criminal Behaviour and Mental Health, 9, |31-143.

Bulik, C. M., Sullivan, P. F., Carter, F. A., et al (1998) The role of exposure with response prevention in the cognitive-behavioral therapy for bulimia nervosa. Psychological Medicine, 28, 611-623.

Fergusson, D. M., Horwood, L. J. \& Lynskey, M. T. (1993) Prevalence and comorbidity of DSM-III-R diagnoses in a birth cohort of 15 year olds. Journal of the American Academy of Child and Adolescent Psychiatry, 6, II27-II34.

Hornblow, A. (1997) New Zealand's health reforms: a clash of cultures. BMJ, 314, 1892-1894.

\& Barnett, P. (2000) A turbulent decade: lesson from the 'health reforms'. New Zealand Medical Journal, II3, 133-134.

McGee, R., Feehan, M., Williams, S., et al (1992) DSM-III-R disorders from age II to age 15 years. Journal of the American Academy of Child and Adolescent Psychiatry, 3I, 50-59.

McIntosh, V.V., Bulik, C. M., McKenzie, J. M., et al (2000) Interpersonal psychotherapy for anorexia nervosa. International Journal of Eating Disorders, 27, 125-139.

Mulder, R. T., Joyce, P. R., Sullivan, P. F., et al (1999) The relationship among three models of personality psychopathology: DSM-III-R personality disorder, TCI scores and DSQ defenses. Psychological Medicine, 29 943-951.

Mullen, P. E., Martin, J. L., Anderson, J. C., et al (1993) Childhood sexual abuse and mental health in adult life. British Journal of Psychiatry, 163, 721-732.

Romans, S. E., Martin, J. L., Anderson, J. C., et al (1995) Factors that mediate between child sexual abuse and adult psychological outcome. Psychological Medicine, 25, $127-142$

Sellman, J. D., Sullivan, P. F., Dore, G. M., et al (200I) A randomized controlled trial of motivational enhancement therapy (MET) for mild to moderate alcohol dependence. journal of Studies on Alcohol, 62, 389-396.

Sullivan, P. F., Fifield, W. J., Kennedy, M. A., et al (1998) No association between novelty seeking and the type 4 dopamine receptor gene (DRD4) in two New Zealand samples. American Journal of Psychiatry, 155, 98-101.

Weissman, M. M., Bland, R. C., Canino, G. J., et a (1996) Cross-national epidemiology of major depression and bipolar disorder. JAMA, 276, 293-299.

Werry, J. S., McClellan, J. M. \& Chard, L. (1991) Childhood and adolescent schizophrenic, bipolar and schizoaffective disorders: a clinical and outcome study. Journal of the American Academy of Child and Adolescent Psychiatry, 30, 457-465.

Peter R. Joyce Department of Psychological Medicine, Christchurch School of Medicine, PO Box 4345, Christchurch, New Zealand 